Please do not remove this page

RMIT

UNIVERSITY

\title{
Inflation targeting in India: A comparison with the multiple indicator approach
}

Mishra, Ankita; Mishra, Vinod

https://researchrepository.rmit.edu.au/esploro/outputs/9921858451901341/filesAndLinks?institution=61RMIT_INST\&index=null

Mishra, A., \& Mishra, V. (2012). Inflation targeting in India: A comparison with the multiple indicator approach. Journal of Asian Economics, 23(1), 86-98. https://doi.org/10.1016/j.asieco.2011.10.003

Published Version: https://doi.org/10.1016/j.asieco.2011.10.003

Repository homepage: https://researchrepository.rmit.edu.au (C) 2011 Elsevier Inc. All rights reserved.

Downloaded On 2023/04/26 19:11:20 +1000 
Thank you for downloading this document from the RMIT Research Repository.

The RMIT Research Repository is an open access database showcasing the research outputs of RMIT University researchers.

RMIT Research Repository: http://researchbank.rmit.edu.au/

\section{Citation:}

Mishra, A and Mishra, V 2012, 'Inflation targeting in India: A comparison with the multiple indicator approach', Journal of Asian Economics, vol. 23, no. 1, pp. 86-98.

See this record in the RMIT Research Repository at:

http://researchbank.rmit.edu.au/view/rmit:16550

Version: Accepted Manuscript

Copyright Statement: (c) 2011 Elsevier Inc

Link to Published Version:

http://dx.doi.org/10.1016/j.asieco.2011.10.003

\section{PLEASE DO NOT REMOVE THIS PAGE}




\title{
Inflation Targeting in India: A Comparison with Multiple Indicator Approach
}

\begin{abstract}
The empirical literature on identification and measurement of the impact of monetary policy shocks on the real side of the economy is fairly comprehensive for developed economies but very limited for emerging and transition economies. In this study, we propose an identification scheme, for a developing economy (taking India as a case study), which is able to capture the monetary transmission mechanism without giving rise to empirical anomalies. We use a VAR approach with recursive contemporaneous restrictions and identify monetary policy shocks by modelling the reaction function of the central bank and structure of the economy. The effect of monetary policy shocks on the exchange rate and other macroeconomic variables is consistent with the predictions of a broad set of theoretical models. This set-up is used to build a hypothetical case of inflation targeting where the monetary policy instrument is set after looking at the current values of inflation only. This is in contrast with the 'multiple indicator approach' currently followed by the Reserve Bank of India. The results in this study suggest that the demand effects of interest rate are stronger than exchange rate effects and there is evidence of mitigation of potential conflict between exchange rate and interest rate, one of main monetary policy dilemmas of the RBI, in the inflation targeting case.
\end{abstract}

Keywords: India, Inflation Targeting, Monetary policy, VAR

JEL codes: E52, E58, E47 


\section{Introduction}

"Monetary Policy is conventionally understood to represent policies, objectives and instruments directed towards regulating money supply and the cost and availability of credit in the economy (Balachandran, 1998). The monetary policy framework can thus be described as deciding the ultimate objectives first; then the intermediate target and lastly the operating procedures of monetary policy involving optimal choice of policy instruments to achieve the ultimate objectives."

The monetary policy framework in India has undergone various transformations since the beginning of the economic planning in 1951. The monetary policy framework, at the beginning of the planning period, could be best described as "controlled expansion" of the money supply. It was determined mainly by the fiscal stance. It was being formulated against the backdrop of large budget deficits. The main task of the Reserve Bank of India (RBI) was to contain the adverse effects of monetization ${ }^{1}$. India switched to a monetary targeting framework in the mid 1980s. Monetary Targeting was pursued in a very flexible manner with a 'feedback' from the real sector of the economy. This was necessary because of the high level of government borrowings and administered interest rates. During this phase, the two core objectives of monetary policy were maintaining price stability and provision of adequate credit to the productive sectors of the economy.

\footnotetext{
${ }^{1}$ Monetization of the deficit is the increase in net RBI credit to the government which, in turn, is the increase in the RBI's holding of government dated securities, 91-day treasury bills and rupee coins for changes in cash balances with the Reserve Bank.
} 
The policy environment, framework and strategies underwent a distinct change in the early 1990s when India adopted economic reforms in 1991 after a balance of payment crisis. Monetary policy had to deal with traditional issues along with the new issues brought about by the changed economic policy environment. Deregulation and liberalization of financial markets started casting doubt on the appropriateness of exclusive reliance on money as the only intermediate target in the late 1990s. The expansion of money supply emanating from monetization of the government deficit and rising capital inflows rendered the control of monetary aggregates more difficult. The gradual opening up of the Indian economy from the 1990s also increased the upward risks to domestic inflation. This emanated from large capital inflows in the economy and a host of other global factors to which domestic inflation was increasingly becoming more responsive. The transition of economic policies from a controlled to liberalized but regulated regime has been reflected in the changes in monetary management in India. The monetary policy framework in India changed from 'pure monetary targeting strategy' to a 'Multiple Indicator Approach (MPA)' in 1998-1999². Though, the basic objectives of monetary policy of price stability and ensuring availability of credit to productive sectors have remained intact, the underlying operating procedures have undergone significant changes. The main attributes of monetary policy in India from mid 1980s to present is summarized in the Table 1.

Insert Table 1 here

\footnotetext{
2 Though, the 'multiple indicator approach' was formally adopted in April 1998, the change in the operating procedure of monetary policy was visible after 1995 only as our analysis in the next section suggests.
} 
This new approach bestowed the RBI with the required flexibility to formulate monetary policy in the face of ongoing financial liberalization and increasing openness. The array of indirect instruments of monetary control available to the RBI has subsequently expanded to maintain orderly conditions in the money and foreign exchange market (Gupta et.al, 2000). The Liquidity Adjustment Facility (LAF) was introduced in 2000, which enabled the RBI to manage liquidity on a daily basis. The LAF is used for absorbing and injecting liquidity through repo and reverse repo operations on a variable rate basis. It has helped in keeping the movements of overnight call rate within a specified corridor and provided monetary authorities with greater flexibility in determining both the quantum of adjustment and rates by responding to the needs of the system on a daily basis. However, the increasing openness of the Indian economy, market determined exchange rate and large capital inflows necessitated sterilizing capital inflows and foreign exchange market intervention. It was initially done through Open Market Operations (OMO) but limited stock of government securities with the RBI under OMO curbed its ability to sterilize. The burden of sterilization consequently shifted to the LAF, which was essentially a tool of marginal liquidity adjustment. In order to absorb liquidity of enduring nature using instrument other than LAF, Market Stabilization Scheme (MSS) was launched in 2004. The instruments of short-term (treasury bills) and medium-term (dated securities) maturities were issued by the government to the RBI under MSS for absorbing liquidity from the system. The MSS empowered RBI to absorb liquidity on a more enduring but temporary basis leaving LAF for daily liquidity management and using OMO on a more enduring basis (Mohan, 2008).

The monetary management in India has been credible so far but the increasing integration of the Indian economy into the world economy after 2000 has lead to the transmission of 
uncertainties related to world financial and oil markets, into the domestic (Indian) economy, hence, making the macroeconomic environment more unpredictable. The monetary framework in India has to adjust to rapid capital inflows and outflows. In this changed scenario, the MPA of monetary policy, which is currently followed by the RBI, does not seem to work effectively. The multiplicity of objectives leads to inherent conflict among such objectives in this environment. This approach is creating a conflict between exchange rate stabilization and inflation stabilization leaving the market confused as which variable the RBI will choose to defend ${ }^{3}$. The monetary impact of capital flows has become a subject of serious discussion in the recent period. The MSS, as the policy instrument for checking monetary expansion out of capital flows, is not working well as incomplete sterilization under MSS is leading to rapid growth in money supply and credit and thus fuelling inflation. The interest costs of MSS is also growing and resulting in large public expenditure ${ }^{4}$. This changed scenario calls for a change to the monetary policy framework to ensure it is transparent and forward-looking with accountability on the part of the central Bank. Inflation targeting by its very nature, encompasses all these properties.

Mishra and Mishra (2009) analyzed the preconditions for inflation targeting in India and assessed its suitability as a monetary policy framework for India. They built sector specific Vector Auto-regression (VAR) models and suggested that the Indian economy satisfies the preconditions for inflation targeting. Extending the analysis of Mishra and Mishra (2009) this paper builds a short run comprehensive VAR model of monetary policy for the Indian economy to examine a hypothetical inflation targeting monetary policy regime for India.

\footnotetext{
${ }^{3}$ To see how refer, for example, to D'souza(2003) and Shah (2007)

${ }^{4}$ Refer to D'souza(2003) and Shah (2007)
} 
The VAR model presented is subjected to monetary policy shocks as different models respond differently to monetary policy shocks. The response of major macroeconomic variables to these shocks will help us determine the type of theoretical model, which can explain all the possible interrelationships among macroeconomic variables and thus fit the framework of the Indian economy better among the variety of models available. Moreover given the theoretical consistency of responses of various macroeconomic variables to monetary shocks, we can conduct the hypothetical experiment of inflation targeting in the above specified VAR model ${ }^{5}$.

Since, the variables are simultaneously determined over time, an identification assumption on contemporaneous causality ${ }^{6}$ is required to be able to isolate monetary policy shocks. We assume that the policy shock is orthogonal to the variables RBI considers while setting its policy instrument. This is referred to as the recursiveness assumption. The economic implication of the recursiveness assumption is that time $t$ variables in the RBI's information set do not respond to time $t$ realizations of monetary policy shocks.

This study contributes to the literature in several ways; first, it suggests an identification scheme which is able to the capture monetary transmission mechanism for a developing economy like India; secondly, it gives preliminary evidence on how an inflation targeting

\footnotetext{
5 This approach is based on Lucas' methodology (see, Christiano et al., 1999).

${ }^{6}$ We placed only short-run restrictions (i.e. restrictions on contemporaneous causality) to identify monetary policy shocks. We did not go into the long-run restrictions structure. Since, we are limiting ourselves to short run (that is the period up to one year); we do not consider issues related to cointegration, which basically studies the existence of long-run equilibrium. .
} 
regime would work for India; and lastly, it will provide implications for the theoretical model which can be used to model monetary policy evolution for India.

The rest of this paper is organized as follows: Section 2 reviews the literature related to the effects of monetary policy shocks; section 3 presents a brief discussion of the VAR and structural VAR methodology as employed in the paper; section 4 outlines structure of the VAR model and the description of the variables included in the model; section 5 presents empirical results and their discussion and section 6 concludes.

\section{Review of Literature}

The literature on the identification of the effects of monetary policy shock to real economy is based on the assumptions about the nature of interaction of this shock with the variables in the central bank's feedback rule, i.e., the rule which relates the central bank's action to the state of the economy. One assumption is that the policy shock is orthogonal to the variables in the feedback rule, usually referred to as 'recursiveness' assumption (Christiano et al., 1999). Much of the work on identification of monetary policy shocks using recursiveness approach is centred on U.S. economy. Some of these studies mainly concentrates on defining the appropriate policy instrument, whose innovations could be called monetary policy shocks, for example, McCallum (1983), Bernanke and Blinder (1992), Eichenbaum (1992), and Christiano and Eichenbaum (1995), Strogin (1995) and so forth; while other studies mainly deal with the effect of monetary policy shocks on various aspects of real economy, for example, Bernanke and Blinder (1992), Christiano and Eichenbaum (1995), Gertler and Gilchrist (1994), Eichenbaum and Evans (1995), Christiano, Eichenbaum and Evans (1996) including others. 
The approach to identify the effects of monetary policy shocks assuming recursiveness corresponds to a notion that economic variables within certain period are determined in a block recursive way. This implies that variables denoting a 'Goods Market'(non policy variables like output, employment, prices etc) are determined first, then the central bank sets its policy instrument and after that the remaining variables in the money market (policy variables like interest rates, credit money supply etc) are determined. Thus abandoning the recursiveness assumption implies dropping the assumption that the central bank only looks at the variables that are predetermined relative to monetary policy shock. Some of the main studies done using non-recursive approach of identification of monetary policy shocks include Sims (1986), Gorden and Leeper (1994), Leeper, Sims and Zha (1996) and Sims and Zha (2006) among others.

The empirical literature that has dealt with the effects of monetary policy shocks has found evidence of several anomalies in both open and closed economy settings. These puzzles as summarized by Kim and Roubini (2000 p.562) are namely the liquidity puzzle, the price puzzle, the exchange rate puzzle and the forward discount bias puzzle ${ }^{7}$. Many studies in the empirical literature have attempted to deal with these puzzles and provided suggestions to explain them, for example Sims (1992) tried to explain the liquidity puzzle, the studies by Christiano, Eichenbaum and Evans (1996) and Sims and Zha (2006) dealt with solving the price puzzle, the studies by Grilli and Roubini (1995), and Cushman and Zha (1997) attempted to explain and solve the exchange rate puzzle for non U.S. G-7 countries and the study by Kim and Roubini (2000) proposed an identification scheme which was successful in

\footnotetext{
${ }^{7}$ For a discussion of the literature that has encountered the mentioned puzzles, refer to Kim and Roubini (2000).
} 
solving the liquidity and exchange rate puzzle and also the forward discount bias puzzle to some extent for non U.S. G-7 countries.

\subsection{Studies on Monetary Policy in India}

The existing literature on identification of monetary policy shocks and their impact on the Indian economy is limited ${ }^{8}$. However, there are some studies available which remotely dealt with the subject. Singh and Kalirajan (2006), for example, modelled the RBI policy reaction function to see how policy stance decisions ${ }^{9}$ respond to the changes in goal variables; namely, output, inflation and the exchange rate. They found that the transmission effects of the RBI's policy stances on the goal variables are not very effective. They suggested that RBI should not be simultaneously working with instruments of quantity and price control. It should concentrate more on price variables for conducting monetary policy with effective interest rate as the main policy instrument.

Singh and Kalirajan (2007) examined the efficacy of interest rate channel of monetary transmission in India in the post reform period ${ }^{10}$. They formulated cointegrated vector autoregression model with generalized restrictions using an open economy framework. Their analysis suggests an important role for interest rate in monetary transmission in post reform India. They concluded that monetary targeting has lost its relevance and the RBI should strengthen its effort to make interest rate the main instrument of monetary policy.

Mohan (2008), surveying the monetary policy transmission for India, suggested that monetary policy impulses impact prices and output through interest rate and exchange rate

\footnotetext{
${ }^{8}$ For literature on inflation targeting as a monetary policy option for India, refer to Mishra and Mishra (2009).

${ }^{9}$ For details on policy instruments and modelling of reaction functions, refer to Singh and Kalirajan (2006).

${ }^{10}$ The process of economic reforms has started in India in 1991.
} 
movements along with the monetary and credit aggregates. He further suggested that emerging market economies like India should allow greater flexibility for the exchange rate and, at the same time, maintain an adequate level of foreign exchange reserves in view of the volatility observed in international capital flows.

There are also a few descriptive studies available which deal with the issues of monetary policy formulation (for e.g., Rangarajan (2001) and Vasudevan (2002)), limitations and constraints in pursuing monetary policy objectives (for e.g., Kanagasabapathy (2001)) and challenges faced by monetary policy due to increasing financial market reforms and growing linkages to the world economy (for e.g., Ramchandran (2000), Nachane (2005)).

\section{Methodology}

The monetary policy shock is identified as the disturbance term in an equation of the form

$$
S_{t}=f\left(\Omega_{t}\right)+\sigma_{s} \varepsilon_{t}^{S}
$$

Here $S_{t}$ is the instrument of monetary policy and $f$ is a linear function that relates $S_{t}$ to the information set $\Omega_{t}$. The random variable $\sigma_{s} \varepsilon_{t}^{s}$ is a monetary policy shock.

\subsection{Vector Autoregression}

A VAR is a convenient device for summarizing first and second order moment properties of the data. The basic problem with VAR is that a given set of second moments is consistent with many such dynamic response functions. Solving this problem amounts to making explicit assumptions that justify focusing on a particular dynamic response function. A VAR for a k-dimensional vector of variables $Y_{t}$, is given by

$$
Y_{t}=A_{1} Y_{(t-1)}+A_{2} Y_{(t-2)}+\cdots \ldots \ldots \ldots \ldots \ldots A_{p} Y_{(t-p)}+\mu_{t}, E \mu_{t} \mu_{t}^{\prime}=\Sigma
$$


Here, $p$ is a nonnegative integer and $\mu_{t}$ is uncorrelated with all variables dated (t-1) and earlier. Knowing $A_{i}^{s}$, the $\mu_{t}^{\prime} s$ and $\Sigma$ are not sufficient to compute the dynamic response function of $Y_{t}$ to the fundamental economic shock in the economy. The basic reason is that $\mu_{\mathrm{t}}$ is the one step ahead forecast error in $Y_{t}$. Each element of $\mu_{t}$ reflects the effect of all the fundamental economic shocks. There is no reason to presume that any element of $\mu_{t}$ corresponds to a particular economic shock, for example, a monetary policy shock.

This shortcoming can be overcome by rewriting (2) in terms of mutually uncorrelated innovations. Suppose we had a matrix $P$ such that $\Sigma=P P^{\prime}$. If we had such a $P$, then $P^{-1} \Sigma P^{\prime-1}=I_{k}$. This implies that $P$ can be used to orthogonalize $\mu_{t}$. Choosing $P$ is similar to placing identification restrictions on the system of dynamic simultaneous equations. Sims (1980) popularized the method of choosing $P$ to be the Cholesky decomposition of $\Sigma$. The impulse response functions based on this choice of $P$ are known as the orthogonalized impulse response functions. Choosing $P$ to be the Cholesky decomposition of $\Sigma$ is equivalent to imposing a recursive structure for the corresponding dynamic structural equation model.

\subsection{Structural Vector Autoregression}

An alternative to the recursive VAR or temporal ordering of variables is to allow for a more elaborate set of restrictions guided by economic theory. This is referred to as a structural VAR (SVAR). The SVAR approach integrates the need to identify the causal impulse response functions into the model specification and estimation process. Sufficient identification restrictions can be obtained by placing either short run or long run restrictions 
on the model. In this exercise we are going to make use of the structural autoregression with short run restrictions. The short run SVAR model (following from equation2) can be written as:

$$
A\left(Y_{t}-A_{1} Y_{(t-1)} \cdots \cdots \cdots \cdots \cdots \cdots \cdots \cdots-A_{p} Y_{(t-p)}=\mu_{t}=B e_{t}\right.
$$

Here, $\mathrm{A}$ and $\mathrm{B}$ are $\mathrm{KXK}$ non-singular matrices of parameters to be estimated and $e_{t}$ is a $\mathrm{KX} 1$ vector of disturbances for all s $\neq$ t. Sufficient constraints must be placed on $A$ and $B$ so that $P$ is identified. The short run SVAR model chooses $P=A^{-1} B$ to identify causal impulse response functions.

\section{Data and Variables}

The model, used in this study, consists of eight variables, chosen to explain all-possible interrelations between the policy and non-policy variables. The eight variables included in the model consist of two foreign variables and six domestic variables. These form two blocks in the model; one is the foreign block with two variables and next is the domestic block with six variables. The foreign variables are block exogenous to the system. It implies that domestic variables are not entering into the equations of foreign variables either contemporaneously or with a lag. This assumption is made due to the small size of the Indian economy relative to the world economy, which makes it unlikely that domestic variables can explain movements in foreign variables either contemporaneously or with a lag.

The data for the domestic variables has been collected from the, 'Handbook of Statistics on the Indian economy, 2005' an annual publication of the RBI. The crude oil prices data has been sourced from the IMF (http://www.imf.org/external/np/res/commod/datar.csv) and the data for federal funds rate (a proxy for foreign interest rate) is taken from the Federal Reserve 
Bank of New-York (http://www.newyorkfed.org/). The period of analysis for this exercise covers from 1996 January to 2005 March $^{11}$.

\subsection{Variables Included in the Model}

The foreign variables included in the model are oil prices and the federal funds rate. The oil prices are crude oil prices and this is the simple average of three spot prices; Dated Brent, West Texas Intermediate and the Dubai Fateh. The federal funds rate is taken as a proxy for international interest rates. The domestic variables included in the model are three non-policy variables and three policy variables. Non-policy variables are inflation (measured by a rate of change in wholesale price index (WPI)), outputgap (measured as a difference between (log of) 'index of industrial production' (IIP) and its (log of) Hodrick-Prescott trend), exchange rate (as measured by nominal effective exchange rate (NEER)), monetary policy instrument, gross bank credit (GBC) and broad monetary aggregate (M3). The growth rate of reserve money (M0) and the call money rate (CMR) are used as monetary policy instruments (MPI). ${ }^{12}$ The yield of SGL transactions on treasury bills of 91 days (91 day Treasury bill rate) has also been tried as a monetary policy instrument.

\subsection{Structure of the Model}

\footnotetext{
11 This period is chosen because the macro-stabilization program undertaken after the balance-of-payment crisis in 1991 started to show its effect after 1995. And this period was a stable and normal period for formulating an economic model.

12 The yield of SGL transactions on treasury bills of 91 days (91 day Treasury bill rate) had also been tried as a monetary policy instrument. The model with 91 day treasury bill rate gave theoretically inconsistent responses of output and exchange rate to monetary policy shocks. This may be due to the fact that in the period considered here, the monetary policy stance of the RBI was the provision of adequate liquidity to meet credit growth and support investment demand and also to keep vigil on the prices and exchange rate. The RBI mainly influences liquidity in the economy to achieve the mentioned objectives and to influence liquidity the RBI intervenes through the money market. Thus money market rate (CMR) is the better indicator of the stance of the monetary policy.
} 
The following identification structure has been used to isolate monetary policy shocks:

$$
\mathrm{X}_{\mathrm{t}}=\left(\begin{array}{cccccccc}
1 & 0 & 0 & 0 & 0 & 0 & 0 & 0 \\
\mathrm{a}_{21} & 1 & 0 & 0 & 0 & 0 & 0 & 0 \\
\mathrm{a}_{31} & \mathrm{a}_{32} & 1 & 0 & 0 & 0 & 0 & 0 \\
\mathrm{a}_{41} & \mathrm{a}_{42} & \mathrm{a}_{43} & 1 & 0 & 0 & 0 & 0 \\
\mathrm{a}_{51} & \mathrm{a}_{52} & \mathrm{a}_{53} & \mathrm{a}_{54} & 1 & 0 & 0 & 0 \\
\mathrm{a}_{61} & \mathrm{a}_{62} & \mathrm{a}_{63} & \mathrm{a}_{64} & \mathrm{a}_{65} & 1 & 0 & 0 \\
\mathrm{a}_{71} & \mathrm{a}_{72} & \mathrm{a}_{73} & \mathrm{a}_{74} & \mathrm{a}_{75} & \mathrm{a}_{76} & 1 & 0 \\
\mathrm{a}_{81} & \mathrm{a}_{82} & \mathrm{a}_{83} & \mathrm{a}_{84} & \mathrm{a}_{85} & \mathrm{a}_{86} & \mathrm{a}_{87} & 1
\end{array}\right)\left(\begin{array}{c}
\text { oil } \\
\text { ffrate } \\
\mathrm{y} \\
\text { inf } \\
\text { neer } \\
\mathrm{mp} \\
\mathrm{m} 3 \\
\mathrm{bc}
\end{array}\right)
$$

This characterizes the restrictions placed on the contemporaneous relationships among variables. Here, 'oil' is the world oil prices, 'ffrate' is the federal funds rate, ' $y$ ' is outputgap, 'inf' is WPI inflation, 'neer' is NEER, ' $m p$ ' is the monetary policy instrument, and ' $m 3$ 'is broad monetary aggregate and ' $b c$ ' is gross bank credit. The growth rate of reserve money (M0) and the call money rate $(\mathrm{CMR})^{13}$ have been used as monetary policy instruments. Here, oil and ffrate form the foreign block and the remaining variables form the domestic block. In the domestic block outputgap (y) inflation (inf), and the nominal effective exchange rate (neer) form the non-policy block and monetary policy instrument, broad monetary aggregate (m3) and gross bank credit $(b c)$ form the policy block. The ordering of variables within each block, namely, foreign, non policy domestic and policy domestic is based on the results of pair-wise Granger causality testing as represented in Table 2.

Insert Table 2 here

\footnotetext{
${ }^{13}$ It is noteworthy that CMR is not the instrument of monetary policy. It is only an indicator of monetary policy stance and the prevailing liquidity situation in the economy. At the most it can act only as a proxy for the instrument of monetary policy. CMR may not be a very robust proxy for monetary policy instrument as it is only a money market rate, however changes in CMR accurately reflected the monetary policy stance during the period of analysis, therefore we used it as an instrument of the monetary policy.
} 
The non-zero coefficients $a_{i j}$ in the above structure indicate that variable ' $j$ ' affects variable ' $i$ ' instantaneously. The coefficients on the diagonal are normalized to 1 . The system is exactly identified. The international shocks can affect the domestic economy rapidly. Thus, the foreign block variables have an instant effect on all the variables in the domestic block. Output is made to respond to inflation contemporaneously" ${ }^{14}$ The 'monetary policy instrument' equation reflects that it has been set after looking at current values of inflation, outputgap and exchange rate. This assumption is valid for a developing economy like India, where central bank has multiple objectives. Unlike the structure followed for a developed economy (as in Sims and Zha (1995) or Kim and Roubini (2000)) where the exchange rate is considered to be a financial variable and assumed to be affected by all the variables instead of affecting them contemporaneously, in a developing economy central bankers are concerned about movements in exchange rate and take quick actions to smooth out fluctuations. M3 and credit are placed in a policy block after the monetary policy instrument and are assumed to react to monetary policy instrument contemporaneously.

\subsection{Pure Inflation Targeting Case}

In the above-described model, the Reserve Bank's monetary policy reaction function is represented by the ' $m p$ ' equation. This has been made to react contemporaneously to shocks in inflation, output gap and the exchange rate. This is more in line with the 'multiple indicator approach' currently followed by the RBI. To put the case of pure inflation targeting in the above structure, we allow only inflation to enter in the monetary policy reaction function as

\footnotetext{
14 This assumption is motivated by the fact that nominal incomes are fixed in the short-run, meaning so is nominal spending.
} 
represented by the ' $m p$ ' equation. Thus the contemporaneous restriction matrix has been modified in the following way for the pure inflation targeting scenario:

$$
\mathrm{X}_{\mathrm{t}}=\left(\begin{array}{cccccccc}
1 & 0 & 0 & 0 & 0 & 0 & 0 & 0 \\
\mathrm{a}_{21} & 1 & 0 & 0 & 0 & 0 & 0 & 0 \\
\mathrm{a}_{31} & \mathrm{a}_{32} & 1 & 0 & 0 & 0 & 0 & 0 \\
\mathrm{a}_{41} & \mathrm{a}_{42} & \mathrm{a}_{43} & 1 & 0 & 0 & 0 & 0 \\
\mathrm{a}_{51} & \mathrm{a}_{52} & \mathrm{a}_{53} & \mathrm{a}_{54} & 1 & 0 & 0 & 0 \\
\mathrm{a}_{61} & \mathrm{a}_{62} & 0 & \mathrm{a}_{64} & 0 & 1 & 0 & 0 \\
\mathrm{a}_{71} & \mathrm{a}_{72} & \mathrm{a}_{73} & \mathrm{a}_{74} & \mathrm{a}_{75} & \mathrm{a}_{76} & 1 & 0 \\
\mathrm{a}_{81} & \mathrm{a}_{82} & \mathrm{a}_{83} & \mathrm{a}_{84} & \mathrm{a}_{85} & \mathrm{a}_{86} & \mathrm{a}_{87} & 1
\end{array}\right)\left(\begin{array}{c}
\text { oil } \\
\text { ffrate } \\
\mathrm{y} \\
\mathrm{inf} \\
\text { neer } \\
\mathrm{mp} \\
\mathrm{m} 3 \\
\mathrm{bc}
\end{array}\right)
$$

In this scenario while setting up the 'monetary policy' instrument the RBI looks at only inflation. However these restrictions are only on the contemporaneous coefficients and this does not prevent the central bank responding to other variables with a lag.

It is also notable that Inflation forecasts play a central role in inflation targeting framework because it is a forward-looking regime where central bank attempt to control inflation over a targeting horizon of one to two years. Since, central banks do not have perfect control over inflation and inflation reacts to monetary policy changes with long and variable lags and also affected by factors other than monetary policy, inflation forecasts provides for an ideal intermediate target. Keeping this in view, an alternative scenario has been built where the actual inflation is replaced with the forecasted inflation ${ }^{15}$.

\section{Empirical Results and Discussion}

All the series, other than interest rates, are taken at the 1993-94 base period and converted to their natural logarithms. In each equation of the VAR model, a full set of monthly dummies

\footnotetext{
${ }^{15}$ Forecasted inflation is obtained from fitting AR (1) model in WPI inflation series.
} 
have been included to take care of deterministic seasonality. The VAR models are estimated via Iterated Seemingly Unrelated Regression (ISUR). The standard errors for impulse responses and forecast error variance decompositions are obtained via bootstrapping.

\subsection{Stationarity Tests}

We performed the Augmented Dicky Fuller (ADF) test and Phillips Perron (PP), Phillips Denis Kwiatkowski, C. B. Peter, Peter Schmidt, and Yongcheol Shin (KPSS), Graham Elliott, Thomas J. Rothenberg and James H. Stock (ERS) point optimal test and NG and Pierre Perron (Ng-Perron) modified unit root tests for the presence of unit roots in the series. These tests ${ }^{16}$ suggest that all the variables other than the call money rate (CMR) and output gap contain a unit root. The results of these tests are given in Table 3. Thus, we used the first difference of the variables. The variables entering into the estimation are: oil price inflation, change in ffrate, domestic (or WPI) inflation, growth of output, appreciation rate, growth of reserve money $(\mathrm{gmO})$ or the call money rate $(\mathrm{CMR})$ as monetary policy instrument variables, growth of bank credit $(g b c)$ and M3 growth $(g m 3)$. The appropriate lag length for the VAR model estimated has been decided on the basis of Akaike's Information criterion (AIC). ${ }^{17}$ The number of lags included in the VAR model is two.

Insert Table 3 here

\subsection{Results from Benchmark Identification}

\footnotetext{
${ }^{16}$ If three or more tests suggested the presence of unit root in a series, we have taken series to contain a unit root.

17 After fitting the VAR with lags as selected by the AIC criterion, the LM test for autocorrelation in the VAR residuals has been performed and if residuals are found to be autocorrelated at that number of lags, the number of lags has been increased to remove autocorrelation in the residuals.
} 
Figure 1 presents the impulse response functions (IRFs) of domestic variables to one standard deviation (s.d.) positive shock in M0 growth while figure 2 shows impulse response functions of domestic variables to one s.d. CMR shocks. Monetary policy shock, as identified by M0 growth shock, gives the price puzzle as given positive shock to M0 growth there is a fall in inflation. And for output gap, there is a small rise for two months, and then it starts falling. The exchange rate also gives a puzzling result as a positive innovation in M0 growth leads to an appreciating exchange rate. The credit and M3 growth rise following M0 growth shock for approx. four months before falling. After the fall, credit and M3 growth again rise for almost two months before the effect of positive shock in M0 growth on them dies down.

We found that growth in reserve money as an instrument of monetary policy is not working well. This is mainly due to the fact that composition of reserve money has changed in the period considered here, rendering it exogenous to the control of the RBI. The net RBI credit to the government and net foreign exchange assets of the RBI, the two main sources which determine largely the variation in reserve money, the share of former has remained fairly stable for the reference period, and the share of latter has gained importance in the growth of reserve money due to growing openness of financial market. The inflow and outflow of foreign capital would not have put a restraint on the RBI's ability to control reserve money if exchange rate would have been completely floated. However, in Indian case, exchange rate could be best described as a 'managed float' and the RBI intervenes in the foreign exchange market to provide a stable corridor for the exchange rate. Under such situation, the expansion (and contraction) of foreign exchange reserves and therefore its impact on the money supply, remain largely outside the control of the RBI (Ramachandran, 2000). Further, the RBI's ability to conduct OMO without any constraint to successfully sterilize the excess liquidity is 
often checked by the underdeveloped securities market and the growing market borrowing requirement of the government.

Insert Figure 1 here

The model with the CMR as monetary policy instrument gives theoretically consistent results for the major economic variables to one standard deviation positive shock in monetary policy instrument (CMR). There is an immediate fall in inflation and outputgap following a positive CMR shock. The price puzzle, which emerges when monetary policy shocks are identified by M0 growth shock, vanishes when monetary policy shocks are taken as shocks to the interest rate (CMR). The behaviour of exchange rate is also in line with the theory (unlike the model with M0 growth as monetary policy instrument) as a positive innovation to interest rate leads to a rise in (appreciation) of the exchange rate. This gives evidence in support of the fact that the rate variable is more appropriately signalling the stance of monetary policy than the quantity variable.

Insert Figure 2 here

Table 4 presents the Forecast Error Variance Decompositions (FEVDs) for the model in which CMR is used as monetary policy instrument ${ }^{18}$. The results of FEVD for inflation show that neer is playing an important secondary role in explaining movements in inflation. This

\footnotetext{
18 Since, model with interest rate (CMR) gives theoretically consistent results for impulse responses; we have
} included FEVDs from this model due to space constraints. 
indicates the sensitivity of domestic inflation to external fluctuations. Outside fluctuations, as indicated by shocks to neer, are playing an important role in determining inflation. Inflation is affected less by output shocks and more by oil shocks as oil shocks explain almost $11 \%$ of volatility in inflation at a forecasting horizon of a year. This shows that cost-push factors (supply side factors) are more important driving inflation than demand-pull factors (demand side factors). It is also noteworthy that Fuel, Power, Light and Lubricant (FPL\&L) is one of the main constituent series of WPI, representing approximately $14 \%$ of the weight in total WPI basket at 1993-94 prices. Inflation in FPL\&L series was the key driver of overall WPI inflation increase in India, mainly after the period of 2000. While the WPI inflation averaged at around 5\% per annum after 2000, Inflation in FPL\&L category increased at the rate of $10 \%$ per annum from 2000 to 2007 and contributed approximately $48 \%$ to the overall increase in headline inflation (Agarwal, 2009). The analysis here, shows that with increasing globalization of Indian economy, the pass through of international prices to domestic inflation has increased and domestic oil, petroleum and lubricants, in particular, become more sensitive to changes in international crude oil prices after the dismantling of the Administered Price Mechanism (APM) in April, $2002^{19}$.

Variations in neer are largely explained by its own shocks. The result for bank credit shows that it is becoming more responsive to shocks in the interest rate compared to the level of economic activity as proxies by output. This suggests the rising sensitivity of credit to interest rates than to incomes. Exchange rate shocks are playing an important role in explaining

\footnotetext{
19 As the analysis period here covers the period of 1997 East Asian Crisis, in order to see the influence of 1997 East Asian financial crisis on the analysis we have included a dummy variable in our model taking value 1 for the period 1997 July to 1998 July and 0 otherwise. This period roughly conforms to the period of East Asian Crisis. This dummy does not turn out to be significant and inclusion of this dummy does have any effect on the results of this exercise. Therefore in the benchmark model, as presented here, we did not include this dummy.
} 
variations in credit and M3 growth. This result supports the rising importance of the exchange rate channel in the economy.

Insert Table 4 here

We found that our benchmark identification with the interest rate as the monetary policy instrument gave meaningful results. It captured the changing monetary policy dynamics neatly. Estimated contemporaneous structural form coefficients from the VAR model (with the interest rate as the monetary policy instrument), as presented in Table 4, further justified the identification structure. The estimated contemporaneous structural coefficients supported the recursive identification, as the contemporaneous coefficients in their respective equations are significant. The coefficient on oil and the foreign interest rate enter positively and significantly in the inflation equation. This is indicative of quick pass through of outside factors to domestic inflation. The contemporaneous coefficient of output gap is also positive and significant in inflation equation. This suggests the demand side changes do affect domestic inflation in India. However, their effect on domestic inflation seems transient (as suggested by FEVDs) and in the short to medium run domestic inflation is driven more by external factors (as proxies by exchange rate shocks) and supply side factors (as proxies by oil price inflation shocks). These coefficients bring out some interesting facts about the institutional aspect of the Indian economy in the period after the mid 90s. First, the significant coefficients of oil and ffrate in the 'inflation equation' support the fact that much of the WPI inflation is imported in nature. Second, since the oil coefficient is positive, it indicates the increase in international oil prices increases inflation immediately while the ffrate coefficient is negative indicating that rise in the international interest rate is lowering 
inflation domestically. This result gives some important insights into the composition of the domestic money supply in India. Since, a higher interest rate abroad will result in capital outflow from the economy this will, in turn, reduce the domestic money supply and thus lower inflation. This provides evidence that capital inflows form a large part of domestic the money supply in India.

The significant negative coefficient of $C M R$ in the ' $g b c$ equation' implies credit is interest sensitive and effect of interest rate on growth of credit is quick. Further, we found in our earlier results of FEVDs that credit is not much sensitive to output gap shocks. However, the contemporaneous coefficient of output gap in credit equation is significant and positive and this suggest that effect of these shocks on growth of credit is immediate and do not last long while shocks to interest rate have more permanent effect on credit. Another interesting point is the positive coefficient on inflation in M3 growth equation. This again gives some indication about the nature of domestic inflation in India ${ }^{20}$. It suggests that inflation is governed mainly by supply side and external factors and this 'cost push' or supply side inflation may result in sluggishness in domestic activity and thus keeping in mind the growth

${ }^{20}$ The fact that inflation in India was mainly supply side generated and imported in nature had been supported by the various arguments and analysis presented in various RBI publications from time to time. We have collected few of them to support this argument. They are as following:

- The inflation rate came under pressure arising from a negative supply shock emanating from shortage of few food articles and food products.........." (Pg. No. VI -27, Report on currency and Finance 1998-99.)

- On an weighted average basis, the fuel group contributed the maximum to inflation during 200001(Pg.No. I-19, Report on currency and Finance1999-2000.)

- The inflation outcome was characterized by an absence of demand induced pressures.(Annual Report of RBI 2000-01)

- Reflecting the global situation, inflation in India firmed up in the last quarter of 2002-03, driven up by the hardening of international oil prices and supply side pressures on ion items like oil seeds, edible oils and oil cakes. (Chapter 3, Pg. No. 47, Annual Report of RBI 2002-03)

- With increasing globalization of the Indian economy, the pass through of international prices to domestic prices is becoming increasingly evident. (Chapter 3, Pg. No. 45, Annual Report of RBI 2003-04). 
objective of monetary policy, in response to a rise in inflation, there is an immediate increase in M3 to prevent aggregate demand from falling.

Insert Table 5 here

\subsection{Comparison of the Benchmark Model with Pure Inflation Targeting Scenario}

The results from benchmark model with CMR as monetary policy instrument indicate that the identification strategy adopted here is able to capture the features of the Indian monetary policy well and produce theoretically consistent results. This allowed us to use this specification to analyze the hypothetical inflation targeting scenario and compare it with the current monetary policy procedure of the RBI. Figure 3 and Table 6 presents the IRFS and FEVDs respectively of the variables to monetary policy shocks in a hypothetical inflation targeting scenario as built in benchmark identification. In this scenario, positive interest rate shocks generate lesser volatility in inflation as compared to benchmark scenario. Further, in this scenario, the initial effect of interest rate shocks on output gap is stronger, and there is a bigger contraction in output gap while it is lesser on exchange rate and there is much smaller appreciation of exchange rate as compared to benchmark case. These results suggest that under inflation targeting scenario, as built in the model here, changes in monetary policy instrument (interest rate) feed into inflation through changes in aggregate demand while in the benchmark case, these changes seem to feed into inflation through exchange rates. The IRFs in two scenarios also suggest an important caveat that there is greater volatility in exchange rate following a negative monetary policy shock in 'inflation targeting' scenario after initial four months than in the benchmark case though initial effect of this shock is lesser. 
Insert Figure 3 here

In an alternative specification, when forecasts of inflation were used instead of actual inflation, the response of inflation forecasts to the positive interest rate shock was milder than the actual inflation. There was still a fall in inflation following negative monetary policy shock but the magnitude of the fall was smaller. This result seems to suggest that if inflation forecasts were used as an intermediate target in a inflation targeting framework, stronger monetary policy reaction is needed to have the same effect on goal variable (inflation forecasts) than would have required if actual inflation were used as a goal variable. The response of other variables (output, exchange rate, credit M3 growth) to the positive interest rate shock were qualitatively similar as found in the 'pure inflation targeting' scenario.

The FEVDs results further give evidence in support of the results of IRFs. The shocks to output gap explain larger variation of inflation, exchange rate, credit and money supply in the economy as compared to the benchmark case. For example, in the benchmark scenario, shocks to output gap roughly explains $0.4 \%, 3 \%$ and $0.3 \%$ while in inflation targeting scenario, as built here, shocks to output gap roughly explains $10 \%, 10 \%$ and $17 \%$ variance of inflation, growth money supply (M3) and credit respectively at the forecasting horizon of the year. Further, the share of exchange rate shocks explaining variation of inflation, credit and money supply in the economy is reduced as compared to benchmark case. For example, in the benchmark scenario, shocks to exchange rate roughly explains $14 \%, 13 \%$ and $10 \%$ while in inflation targeting scenario, as built here, shocks to exchange rate roughly explains $3 \%, 8 \%$ and $1 \%$ variance of inflation, growth money supply (M3) and credit respectively at the forecasting horizon of the year. These FEVDs results support our earlier results of IRFs that 
much of changes in monetary policy feed into the system through changes in aggregate demand in inflation targeting scenario in contrast to the benchmark case where these changes feed through exchange rate.

Insert Table 6 here

The estimated structural contemporaneous coefficients do not change much across the two scenarios.

Insert Table 7 here

\section{Conclusions}

This paper builds a short-run Vector Autoregression model of monetary policy for India. The RBI's reaction function or feedback rule to changes in the foreign shocks and non policy variables determines the setting of the policy instrument variable. In the base-case scenario, the monetary policy instrument is set after looking at current values of inflation, output and exchange rate. This is more in line with the 'multiple indicators' approach followed by the RBI. The model with interest rate as monetary policy instrument behaved consistently. Responses to monetary shock are in directions suggested by theory and thus, it can be considered as a good approximation of reality.

Therefore in the above structure, we put in the case of 'pure inflation targeting' to see how hypothetical inflation targeting regime would work for India. For this, we made monetary 
policy instrument to react only to inflation contemporaneously. The hypothetical inflation targeting regime, as built here, suggests that demand effects of changes in interest rate is stronger than exchange rate effects. The increase in interest rate (or negative monetary policy shocks) does not appreciate exchange rate as much in the inflation targeting scenario as in the benchmark case and inflation stabilization comes basically from output gap changes in inflation targeting scenario. This very basic model on the working of inflation targeting regime for India suggest that much of the changes in economy are operating through changes in domestic demand in inflation targeting scenario in contrast to the benchmark case where these changes operate through exchange rate. This seems a better a outcome over benchmark case (more in line with the Multiple Indicator Approach of the RBI) primarily because changes in exchange rate are more complex to decipher as exchange rate, besides being affected by the realized changes in interest rate, would also be affected by the expectations of future interest rate. And also, there is an evidence that in inflation targeting scenario, the potential conflict between exchange rate and interest rate in an open economy context, one of the main monetary policy dilemma of the RBI, seems to be mitigated as initial reaction of exchange rate to interest rate changes are milder in comparison to multiple indicator (benchmark) scenario.

The main policy implication, as the analysis here on two alternative monetary policy regimes seem to suggest, that the RBI may achieve a better monetary management shifting to a inflation targeting framework. Another policy implication is on the management of inflation and credit situation in the economy and it seems that RBI may be able to affect inflation outcomes immediately by altering demand side factors. However, their effect on inflation will be transient; sustained and stable inflation situation can be achieved by improving the supply side of the economy. It also appears that credit in the economy is affected by direct interest rate changes and also indirect effects of interest rate changes which feed into it through 
changes in demand side factors. However, the effect of demand side factors on credit is temporary, which implies that RBI should exercise caution on interest rate changes to alter credit situation in the economy as any effect of interest rate change on credit might be stronger immediately than what would have been required (or intended).

The VAR model also highlighted the determinants of inflation volatility in India since mid 1990s. Inflation in India is mainly affected by global supply factors and external fluctuations. Moreover, the pass through of these international shocks to domestic inflation is quite rapid as the estimated structural contemporaneous coefficient from VAR model showed.

An interesting area for future research would be to develop the theoretical model for monetary policy in India incorporating the stylized facts ${ }^{21}$ as suggested by the VAR model in this exercise and use this for evaluating the inflation targeting monetary policy framework for India. Another interesting extension of this study could be to use the long run restrictions or combination of short run and long run restriction structure to identify and examine impact of monetary policy shocks on real economy.

\footnotetext{
21 The VAR model suggested 'New Keynesian' framework with incorporation some form stickiness in the prices giving rise to non-neutral effects of monetary policy is needed to prepare the framework suitable for the evolution of monetary policy. Second, call money rate shocks gave theoretically consistent results for the major macro economic variables (output, inflation and exchange rate). This suggests that rate variables are better in signalling the stance of monetary policy for India than quantity variables and justifies the use of nominal interest rate as an instrument. Third, there is a growing importance of exchange rate channel in the transmission of monetary policy in India. The exchange rate shocks are playing central role in explaining the volatility of inflation, interest rate, growth of credit and money supply growth in India.
} 


\section{References}

Annual Report of RBI (2000/2001, 2002/2003, 2003/2004), RBI publication

Agarwal, A. (2009), "Inflation Targeting in India: An Explorative Analysis", Chapter 1, PhD thesis, IGIDR, India.

Balachandran, A. (1998), “The Reserve Bank of India, 1951-1967”, Oxford University Press

Bernanke, B.S. and Blinder, A.S. (1992), "The Federal Funds Rate and the Channels of Monetary Transmission”, American Economic Review 82(4), 901-921

Christiano, L.J. and Eichenbaum, M. (1995), "Liquidity Effects, Monetary Policy and the Business Cycle”, Journal of Money, Credit and Banking 27(4), 1113-1136

Christiano, L.J., Eichenbaum, M. and Evans, C.L. (1996), “The Effects of Monetary Policy Shocks: Evidence from the Flow of Funds", Review of Economics and Statistics 78(1), 1634.

Christiano, L.J., Eichenbaum, M. and Evans, C.L. (1999), "Monetary Policy Shocks: What Have We learned and to What End?" Handbook of Macroeconomics, Volume1, Chapter 2, $65-148$

Cushman, D.O. and Zha, T. (1997), "Identifying Monetary Policy in a Small Open Economy under Flexible Exchange Rates”, Journal of Monetary Economics 39(3), 433-448

D’Souza, E. (2003), "What is Monetary Policy Doing?" Economic and Political Weekly, Vol.38, No.8, 821-823

Eichenbaum, M. (1992), "Comment on Interpreting the Macroeconomic Time Series Facts: The Effects of Monetary Policy", European Economic Review 36(5), 1001-1011

Eichenbaum, M. and Evans, C.L. (1995), "Some Empirical Evidence on the Effects of Shocks to Monetary Policy on Exchange Rates", Quarterly Journal of Economics 110(4), 1975-1010.

Gertler, M. and Gilchrist, S. (1994), "Monetary Policy, Business Cycles and the Behaviour of Small Manufacturing Firms", Quarterly Journal of Economics, 109, 309-340 
Grilli, N. and Roubini, N. (1995), "Liquidity Models in Open Economies: Theory and Empirical Evidence”, NBER W.P. No. 5313, October.

Gorden, D.B. and Leeper, E.M. (1994), "The Dynamic Impacts of Monetary Policy: An Exercise in Tentative Identification”, Journal of Political Economy 102, 228-247

Gupta, I. S., Bhattacharyya, I., Sahoo, S. and Sanyal, S. (2000), "Anatomy of Liquidity Management”, Reserve Bank of India Occasional Papers 21(2-3), 291-321

Handbook of Statistics on Indian Economy (2005), RBI Publication

Kanagasabapathy, K. (2001), "Monetary Policy Underpinnings", Economic and Political Weekly, Vol.36, No.4, 303-310

Kim, S. and Roubini, N. (2000), "Exchange Rate Anomalies in Industrial Countries: A Solution with Structural VAR Approach”, Journal of Monetary Economics 45, 561-586

Leeper, E.M., Sims, C.A. and Zha, T. (1996), "What Does Monetary Policy Do?" Brookings Papers on Economic Activity, 2, 1-63.

McCallum, B.T. (1983), “A Reconsideration of Sims’ Evidence Regarding Monetarism,' Economic Letters, 13(2-3), 167-171

Mishra, A. and Mishra, V. (2009), "Preconditions for Inflation Targeting in an Emerging Economy: The Case of India,' DRU Working Paper No. DEVDP 09-08, Development Research Unit, Monash University

Mohan, R. (2008), “Monetary Policy Transmission in India,’ BIS Paper No.35, 259-307

Nachane, D.M. (2005), "Some Reflections on Monetary Policy in Leaden Age", Economic and Political Weekly, Vol.40, No.28, 2990-2993

Rangarajan, C. (2001), "Some Critical Issues in Monetary Policy", Economic and Political Weekly, Vol.36, No.24, 2139-2146

Ramachandran, M. (2000), "Fiscal Deficit, RBI Autonomy and Monetary Management", Economic and Political Weekly, Vol.35, No.35-36, 3266-3272

Report on Currency and Finance (1996/97, 1998/99, 1999/2000), RBI publication 
Shah, A. (2007), "Righting the Rupee", Asian Wall Street Journal (18 May)

Sims, C.A (1980), “Macroeconomics and Reality”, Econometrica Vol.48 (1), 1-48

Sims, C.A (1986), “Are Forecasting Models Usable for Policy Analysis?” Minneapolis Federal Reserve Bank Quarterly Review, winter, 2-16

Sims, C.A (1992), "Interpreting the Macroeconomic Time Series Facts: The Effects of Monetary Policy", European Economic Review, 36,975-1000

Sims, C.A. and Zha, T. (2006), "Does Monetary Policy Generate Recessions? Macroeconomic Dynamics, Vol.10, No.2, 231-273

Singh, K. and Kalirajan, K.P. (2006), "Monetary Policy in India: Objectives, Reaction Function and Policy Effectiveness" Review of Applied Economics, Vol.2, No.2, 181-199

Singh, K. and Kalirajan, K.P. (2007), "Monetary Transmission in the Post-Reform India: An Evaluation" Journal of the Asia Pacific Economy, Vol.12, No.2, 158-187

Strogin, S. (1995), "The Identification of Monetary Policy Disturbances: Explaining the Liquidity Puzzle”, Journal of Monetary Economics 34(3), 463-497

Vasudevan, A. (2002), "Evolving Monetary Policy in India: Some Perspectives", Economic and Political Weekly, Vol.37, No.11, 1055-1061 
Appendix: Tables and Figures

Figure 1: Positive M0 Shock (Positive Monetary Shock) in a Benchmark Case

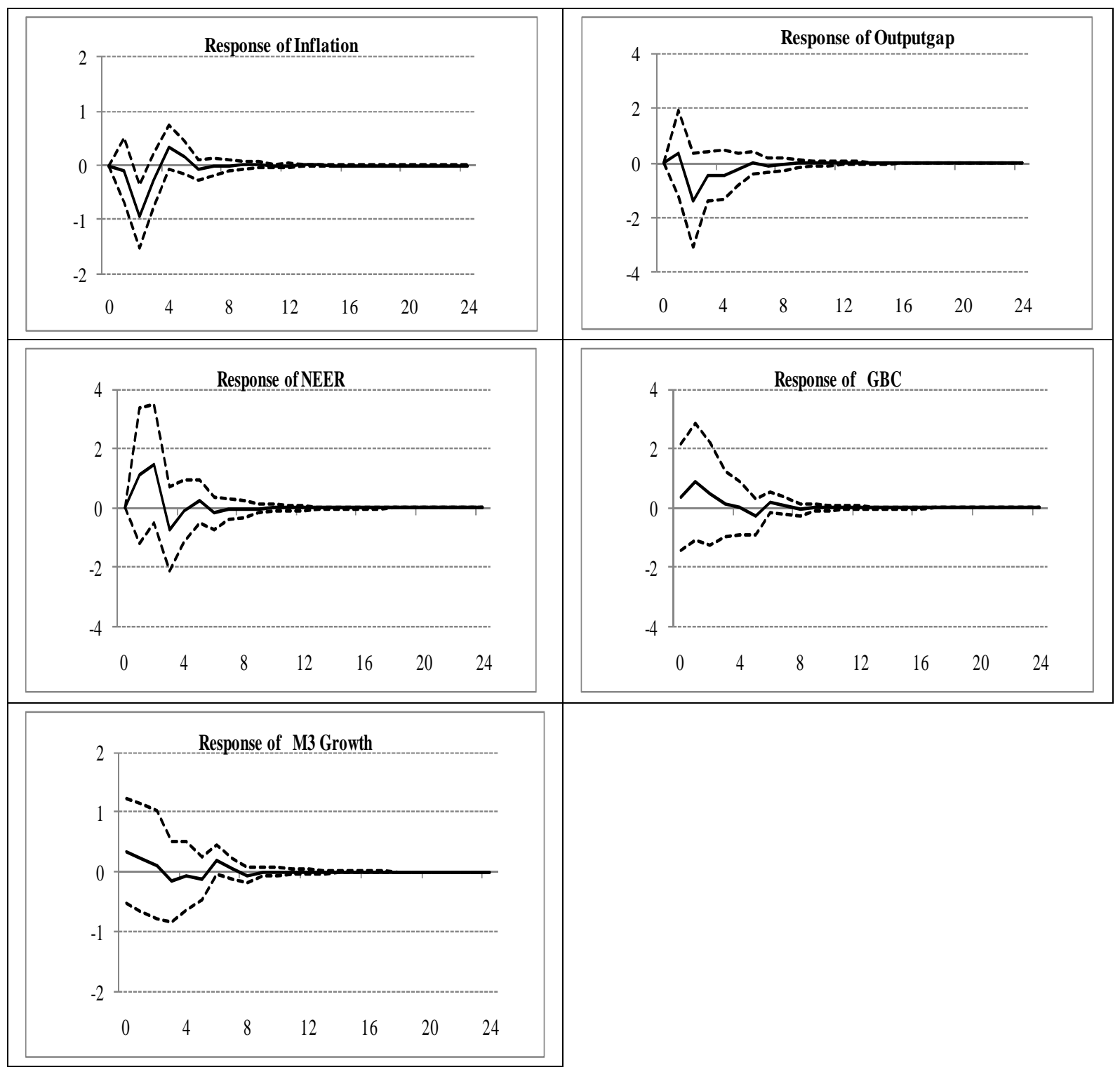


Figure 2: Positive CMR Shock (Negative Monetary Shock) in a Benchmark Case

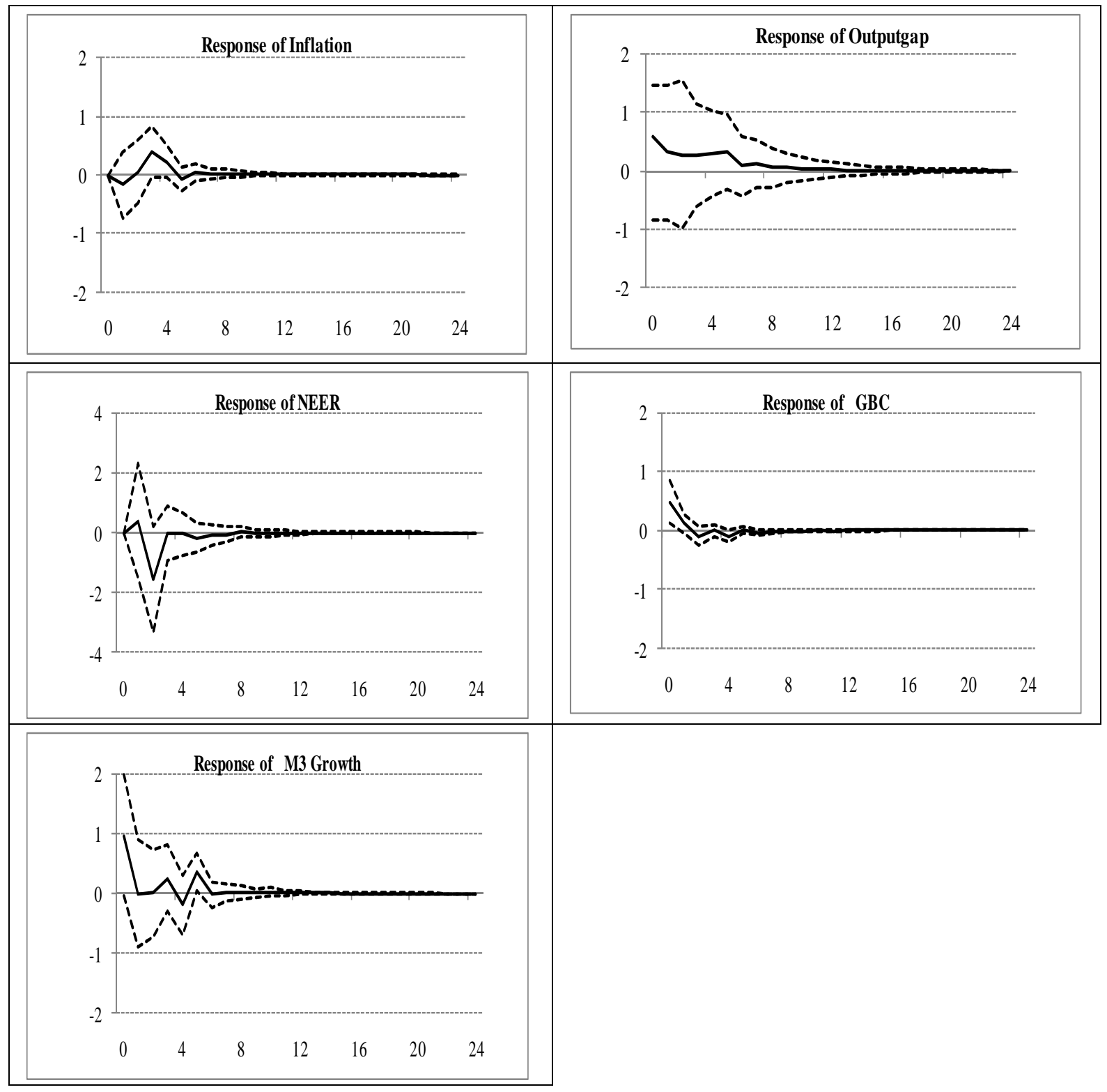


Figure 3: Positive CMR Shock (Negative Monetary Shock) in an Inflation Targeting Case

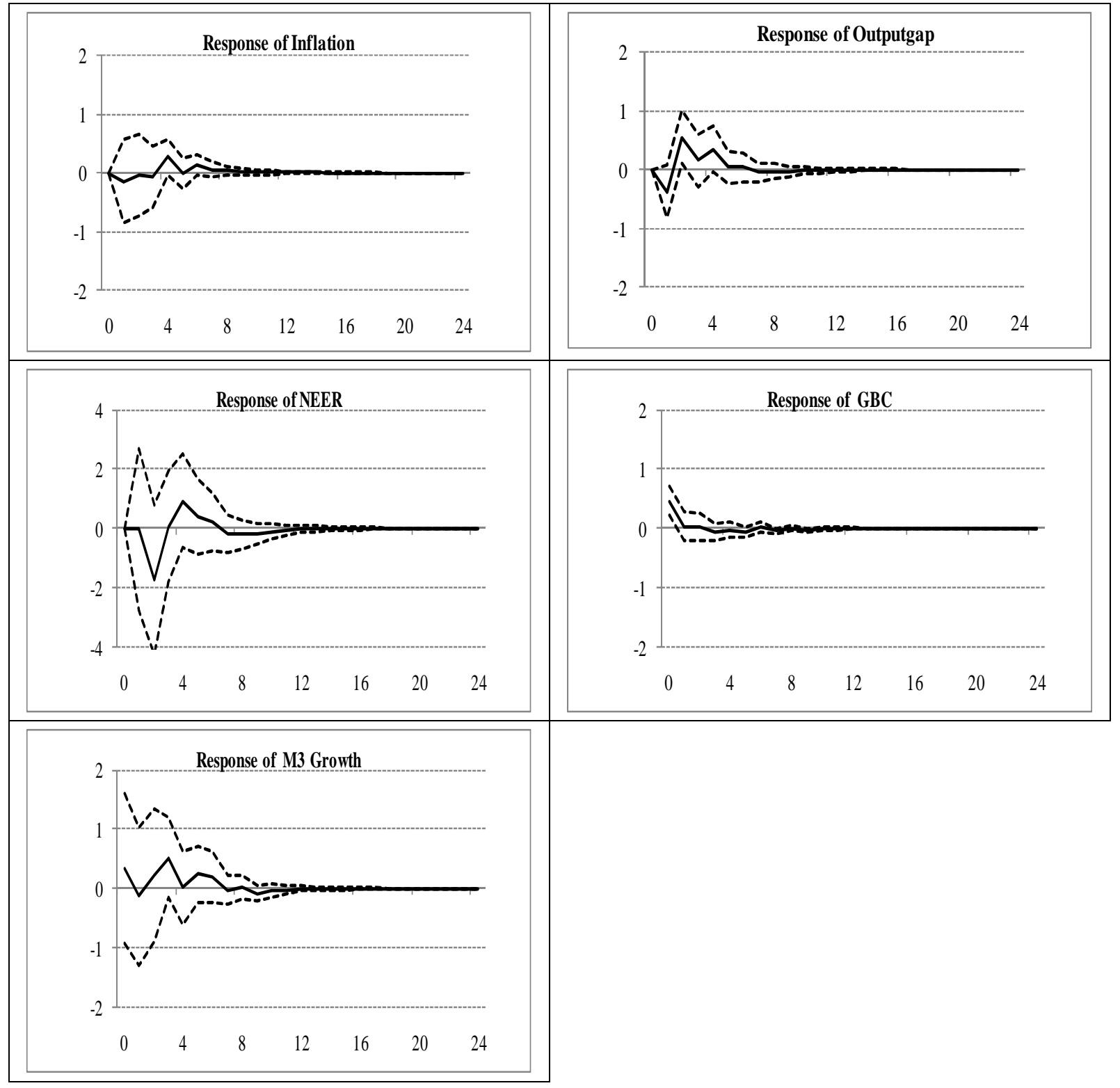


Table 1: Main Attributes of Monetary policy In India

\begin{tabular}{|c|c|c|}
\hline Attribute & Mid 1980s to $1998-99$ & 1998-99 to Present \\
\hline Objective(s) & $\begin{array}{l}\text { 1) Price Stability } \\
\text { 2)Ensuring adequate flow of credit } \\
\text { to productive sectors of the } \\
\text { economy }\end{array}$ & $\begin{array}{l}\text { 1)Price Stability } \\
\text { 2)Ensuring adequate flow of credit } \\
\text { to productive sectors of the } \\
\text { economy }\end{array}$ \\
\hline $\begin{array}{l}\text { Transmission } \\
\text { Mechanism (or } \\
\text { intermediate } \\
\text { target) }\end{array}$ & $\begin{array}{l}\text { Monetary Targeting with annual } \\
\text { growth in broad money }\left(\mathrm{M}_{3}\right) \text { as } \\
\text { intermediate target }\end{array}$ & $\begin{array}{l}\text { Multiple Indicator approach with } \\
\text { rate of returns in different markets } \\
\text { (namely money, capital, currency, } \\
\text { external etc.) as intermediate } \\
\text { target }\end{array}$ \\
\hline $\begin{array}{l}\text { Operating } \\
\text { Procedure } \\
\text { (Instruments) }\end{array}$ & $\begin{array}{l}\text { Direct instruments namely interest } \\
\text { rate regulations, selective credit } \\
\text { control and Cash Reserve Ratio } \\
(\mathrm{CRR})\end{array}$ & $\begin{array}{l}\text { Indirect instruments namely repo } \\
\text { operations under Liquidity } \\
\text { Management Facility (LAF) and } \\
\text { Open Market Operations(OMO) }\end{array}$ \\
\hline
\end{tabular}

Source: Agarwal (2009) 
Table 2: Results of Pair-wise Granger Causality Test

\begin{tabular}{lcc}
\hline Null Hypothesis & F-Statistic & Prob. \\
\hline Non-Policy Block & & \\
\hline inf does not Granger Cause outputgap & 3.900 & 0.446 \\
outputgap does not Granger Cause inf & 4.445 & 0.005 \\
neer does not Granger Cause outputgap & 5.949 & 0.002 \\
outputgap does not Granger Cause neer & 0.816 & 0.517 \\
neer does not Granger Cause inf & 2.953 & 0.023 \\
inf does not Granger Cause $n e e r$ & & \\
\hline Policy Block & 0.694 & 0.597 \\
\hline gm3 does not Granger Cause CMR & 2.388 & 0.056 \\
CMR does not Granger Cause $g m 3$ & 1.417 & 0.234 \\
gbc does not Granger Cause CMR & 1.474 & 0.216 \\
CMR does not Granger Cause $g b c$ & 1.112 & 0.355 \\
gbc does not Granger Cause $g m 3$ & 4.485 & 0.002 \\
gm3 does not Granger Cause $g b c$ & & \\
\hline
\end{tabular}


Table 3: Results for unit root tests

\begin{tabular}{|c|c|c|c|c|c|}
\hline Variable & ADF Test & PP Test & KPSS Test & $\begin{array}{l}\text { ERS Point } \\
\text { Optimal } \\
\text { Test }\end{array}$ & $\begin{array}{l}\text { Ng-Perron } \\
\text { Modified } \\
\text { Unit root } \\
\text { Test } \\
\end{array}$ \\
\hline OIL & -1.17 & -1.07 & $0.80 * * *$ & 6.98 & -3.91 \\
\hline FFRATE & -0.98 & -1.05 & $0.92 * * *$ & 19.37 & -1.19 \\
\hline WPI & -0.56 & -0.48 & $1.21 * * *$ & 632.03 & 1.68 \\
\hline Outputgap & $-7.78 * * *$ & $-7.45 * * *$ & 0.01 & $0.57 * * *$ & $-134.34 * * *$ \\
\hline CMR & $-6.03 * * *$ & $-5.87 * * *$ & $0.70 * *$ & $2.45^{* *}$ & $-9.11 * *$ \\
\hline M0 & 0.06 & 1.84 & $1.21 * * *$ & 231.53 & 2.03 \\
\hline $\mathrm{BC}$ & 1.92 & 2.26 & $1.22 * * *$ & 1258.4 & 2.22 \\
\hline M3 & -1.54 & $-3.34 * *$ & $-1.21 * * *$ & 4141.1 & 1.57 \\
\hline NEER & -0.11 & -0.39 & $0.63 * *$ & $1.47 * * *$ & $-17.93 * * *$ \\
\hline \multicolumn{6}{|c|}{ After First Differencing } \\
\hline$\Delta \mathrm{OIL}$ & $-10.45^{* * *}$ & $-10.47 * * *$ & 0.15 & $0.55 * * *$ & $-45.1 * * *$ \\
\hline$\triangle$ FFRATE & $-5.07 * * *$ & $-5.05 * * *$ & 0.12 & $2.13 * *$ & $-10.89 * *$ \\
\hline$\Delta \mathrm{WPI}$ & $-8.34 * * *$ & $-8.22 * * *$ & 0.05 & $0.52 * * *$ & $-50.50 * * *$ \\
\hline$\Delta$ Outputgap & - & - & - & - & - \\
\hline$\Delta \mathrm{CMR}$ & - & - & - & - & - \\
\hline$\Delta \mathrm{M} 0$ & $-11.18 * * *$ & $-16.91 * * *$ & $0.50 * *$ & $0.94 * * *$ & -3.78 \\
\hline$\Delta \mathrm{BC}$ & $-10.64 * * *$ & $-10.65 * * *$ & $0.38 *$ & $0.58 * * *$ & $54.43 * * *$ \\
\hline$\Delta \mathrm{M} 3$ & $-7.92 * * *$ & $-9.76 * * *$ & $0.43 *$ & $0.11 * * *$ & $-163.05 * * *$ \\
\hline$\triangle$ NEER & $-7.82 * * *$ & $-12.13 * * *$ & 0.14 & $1.95 * * *$ & $-46.94 * * *$ \\
\hline
\end{tabular}

Notes: (1.) For the ADF test the lag length was selected by using SIC (Modified SIC for ERS $\&$ Ng-Perron) values. (2.) For PP and KPSS test the optimal bandwidth was selected by Newey-West method using Bartlett kernel. (3.) All the unit root tests were performed with the assumption of constant term in the logarithm of the series (except for CMR and ffrate) with the null hypothesis of unit root for all tests except for KPSS test where null was stationarity $(4 .)^{*}\left(^{* *}\right)^{* * *}$ denote statistical significance at the $10 \%, 5 \%$ and $1 \%$ levels respectively. 
Table 4: Forecast Error Variance Decomposition in a Benchmark Case

(CMR as Monetary Policy Instrument)

\begin{tabular}{|c|c|c|c|c|c|c|c|c|}
\hline \multicolumn{9}{|c|}{ e of Inflation as Explained by Shocks to } \\
\hline Horizon & oil & ffrate & outputgap & inf & neer & $C M R$ & $g m 3$ & $g b c$ \\
\hline 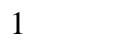 & $10.40(6.9)$ & $4.18(5.6)$ & $0.03(1.5)$ & $85.39(7.5)$ & $0.00(0.0)$ & $0.00(0.0)$ & $0.00(0.0)$ & $\overline{0.00(0.0)}$ \\
\hline & 10.72( & 7.01 & & 64.64 & 12.60 & 0.1 & 4) & \\
\hline & 10.80( & 7.13 & ) & 62.17( & 13.54 & 1.02 & 3.12 & $1.82(1.8)$ \\
\hline 2 & $10.79(5.4)$ & $7.36(5.2)$ & $0.39(1.8)$ & $61.97(7.4)$ & $13.51(6.7)$ & $1.03(1.9)$ & $3.12(2.2)$ & $1.83(1.8)$ \\
\hline \multicolumn{9}{|c|}{ orecast Error Variance of Outputgap as Explained by Shocks to } \\
\hline orizon & oil & ffrate & outputgap & inf & neer & $C M R$ & $g m 3$ & $g b c$ \\
\hline & $0.86(3.2)$ & $0.37(3.1)$ & $98.77(4.3)$ & $0.00(0.0)$ & $0.00(0.0$ & $0.00(0.0)$ & $0.00(0.0)$ & $0.00(0.0)$ \\
\hline & $0.88(3.5)$ & 1.26( & 92.72( & 3.88 & $0.55(2$ & $0.13(0.7)$ & $0.52(1.8)$ & $0.06(1.4)$ \\
\hline & $0.95(3$ & 1.40( & 91.73 & 3.980 & $0.94(2$ & 0.31 & $0.54(1.8)$ & $0.15(1.5)$ \\
\hline 2 & $0.98(3.3)$ & $1.70(5.2)$ & $91.38(7.3)$ & $3.98(3.5)$ & $0.94(2.8)$ & $0.33(1.2)$ & $0.54(1.8)$ & $0.15(1.5)$ \\
\hline
\end{tabular}

\begin{tabular}{|c|c|c|c|c|c|c|c|c|}
\hline \multicolumn{9}{|c|}{ of NEER as Explained by Sho } \\
\hline Horizon & oil & ffrate & outputgap & inf & neer & $C M R$ & $g m 3$ & $g b c$ \\
\hline 1 & $1.45(3.8)$ & $0.31(2.0)$ & $0.73(1.6)$ & $2.78(3.4)$ & $94.73(4.8)$ & $0.00(0.0)$ & $0.00(0.0)$ & $0.00(0.0)$ \\
\hline 3 & $2.58(4.2)$ & $1.44(3.3)$ & 0.80 & $3.10(3.3)$ & 87.80 & $1.26(1.9)$ & 2.90 & $0.12(1.2)$ \\
\hline 6 & $2.68(4.2)$ & $1.63(3.4)$ & 0.90 & $3.28(3.2)$ & $86.99(6.7)$ & $1.27(1.8)$ & $2.68(3.0)$ & $0.24(1.3)$ \\
\hline 12 & $2.68(4.1)$ & $1.71(3.4)$ & 0.90 & $3.28(3.2)$ & $86.89(6.7)$ & $1.27(1.9)$ & 3.02 & $0.25(1.3)$ \\
\hline \multicolumn{9}{|c|}{ Forecast Error Variance of CMR as Explained by Shocks to } \\
\hline Horizon & oil & ffrate & outputgap & inf & neer & $C M R$ & $g m 3$ & $g b c$ \\
\hline & $0.96(3.4)$ & $0.21(1.5)$ & $0.07(1.3)$ & $0.36(2.1)$ & $0.38(1.5)$ & $98.02(4.5)$ & $0.00(0.0)$ & $0.00(0.0)$ \\
\hline & $1.44(3.6)$ & $0.24(2.3)$ & 1.31 & 2.41(4.2) & $6.46(6.2)$ & $84.74(9.3)$ & 0.83 & $2.58(3.5)$ \\
\hline & $1.54(3.6)$ & 0.59 & 1.86 & $2.49(4.1)$ & $6.73(6.1)$ & $82.22(10.1)$ & 1.10 & $3.46(4.0)$ \\
\hline 12 & $1.53(3.7)$ & $0.71(4.0)$ & $1.99(3.9)$ & $2.48(4.0)$ & $6.81(6.1)$ & $81.82(10.4)$ & $1.10(1.7)$ & $3.57(4.1)$ \\
\hline \multicolumn{9}{|c|}{ Forecast Error Variance of GM3 as Explained by Shocks to } \\
\hline Horizon & oil & ffrate & outputgap & inf & neer & $C M R$ & $g m$ & $g b c$ \\
\hline & $0.30(2.6)$ & $0.27(2.0)$ & 1.34 & $5.07(4.5)$ & $0.51(2.3)$ & $2.86(3.7)$ & 89.65 & $0.00(0.0)$ \\
\hline & $2.97(4.2)$ & $0.79(2.3)$ & 2.73 & $7.05(4.4)$ & $8.53(4.4)$ & $2.19(2.6)$ & $70.78(7.3)$ & $4.97(3.1)$ \\
\hline & $3.11(3.9)$ & $0.81(2.3)$ & $2.66(3.2)$ & $7.23(3.9)$ & $12.69(5.6)$ & $2.49(2.4)$ & $65.29(7.3)$ & $5.71(3.1)$ \\
\hline 12 & $3.12(3.9)$ & $0.88(2.3)$ & 2.66(3.2) & 7.23(3.9) & $12.69(5.6)$ & $2.49(2.4)$ & $65.20(7.3)$ & $5.73(3.1)$ \\
\hline \multicolumn{9}{|c|}{ Forecast Error Variance of GBC as Explained by Shocks to } \\
\hline Horizon & oil & ffrate & outputgap & inf & neer & $C M R$ & $g m 3$ & $g b c$ \\
\hline & $0.01(2.5)$ & $0.10(1.8)$ & $0.02(1.3)$ & $0.01(1.0)$ & $0.02(1.5)$ & $17.89(11.0)$ & $24.56(7.7)$ & $57.35(9.7)$ \\
\hline & $0.05(3.0)$ & $2.78(3.8)$ & & $1.45(2.8)$ & $8.23(5.4)$ & $15.97(8.7)$ & $22.30(6.6)$ & 49.34(7.7) \\
\hline & $0.83(2.9)$ & $3.47(4.1)$ & 0.29 & $1.38(2.6)$ & $10.06(6.1)$ & $15.70(8.1)$ & $21.30(6.1)$ & $47.10(7.4)$ \\
\hline & $0.88(3.0)$ & $3.64(4.3)$ & $0.29(2.4)$ & $1.39(2.6)$ & $10.05(6.1)$ & $15.74(8.1)$ & $21.24(6.1)$ & $46.91(7.4)$ \\
\hline
\end{tabular}

Note: Figures in brackets are standard errors calculated via boot strapping method. 
Table 5: Estimated Structural Contemporaneous Coefficients

(Benchmark Case)

\begin{tabular}{|c|c|c|c|c|c|c|c|c|}
\hline & oil & ffrate & outputgap & $\inf$ & neer & $C M R$ & $g m 3$ & $g b c$ \\
\hline oil & $\begin{array}{l}7.941 * * * \\
(0.54)\end{array}$ & & & & & & & \\
\hline ffrate & $\begin{array}{l}-1.305^{*} \\
(0.77)\end{array}$ & $\begin{array}{l}7.652 * * * \\
(0.52)\end{array}$ & & & & & & \\
\hline outputgap & $\begin{array}{l}-2.463 \text { *** } \\
(0.79)\end{array}$ & $\begin{array}{l}-0.764 \\
(0.74)\end{array}$ & $\begin{array}{l}35.541 \text { *** } \\
(2.42)\end{array}$ & & & & & \\
\hline inf & $\begin{array}{l}5.107 * * * \\
(0.88)\end{array}$ & $\begin{array}{l}-1.729^{* * *} \\
(0.75)\end{array}$ & $\begin{array}{l}9.742 * * * \\
(3.48)\end{array}$ & $\begin{array}{l}253.068^{* * *} \\
(17.22)\end{array}$ & & & & \\
\hline neer & $\begin{array}{l}1.518 \\
(0.95)\end{array}$ & $\begin{array}{l}-0.466 \\
(0.76)\end{array}$ & $\begin{array}{l}0.741 \\
(3.55)\end{array}$ & $\begin{array}{l}14.837 \\
(24.37)\end{array}$ & $\begin{array}{l}59.916^{* * * *} \\
(4.08)\end{array}$ & & & \\
\hline$C M R$ & $\begin{array}{l}1.241 \\
(0.96)\end{array}$ & $\begin{array}{l}-0.165 \\
(0.76)\end{array}$ & $\begin{array}{l}-2.889 \\
(3.55)\end{array}$ & $\begin{array}{l}8.240 \\
(24.40)\end{array}$ & $\begin{array}{l}0.616 \\
(5.77)\end{array}$ & $\begin{array}{l}0.415^{* * * *} \\
(0.03)\end{array}$ & & \\
\hline gm 3 & $\begin{array}{l}1.534 \\
(0.97)\end{array}$ & $\begin{array}{l}0.326 \\
(0.76)\end{array}$ & $\begin{array}{l}-2.656 \\
(3.562\end{array}$ & $\begin{array}{l}42.356^{*} \\
(24.58)\end{array}$ & $\begin{array}{l}-10.785^{*} \\
(5.81)\end{array}$ & $\begin{array}{l}-0.020 \\
(0.04)\end{array}$ & $\begin{array}{l}149.198 * * * \\
(10.15)\end{array}$ & \\
\hline$g b c$ & $\begin{array}{l}-0.222 \\
(0.98)\end{array}$ & $\begin{array}{l}0.840 \\
(0.76)\end{array}$ & $\begin{array}{l}16.114 * * * \\
(3.73)\end{array}$ & $\begin{array}{l}25.890 \\
(24.81)\end{array}$ & $\begin{array}{l}11.599 * * \\
(5.91)\end{array}$ & $\begin{array}{l}-0.173 * * * \\
(0.04)\end{array}$ & $\begin{array}{l}108.187^{* * * *} \\
(16.13)\end{array}$ & $\begin{array}{l}99.292 * * * \\
(6.76)\end{array}$ \\
\hline
\end{tabular}


Table 6: Forecast Error Variance Decomposition in a Pure Inflation Targeting Case

\begin{tabular}{lcccccccc}
\hline \multicolumn{2}{l}{ Forecast Error Variance of Inflation as Explained by Shocks to } \\
\hline Horizon & oil & ffrate & outputgap & inf & neer & CMR & gm3 & $g b c$ \\
\hline 1 & $11.27(5.5)$ & $2.47(2.5)$ & $4.70(3.3)$ & $81.57(9.3)$ & $0.00(0.0)$ & $0.00(0.0)$ & $0.00(0.0)$ & $0.00(0.0)$ \\
3 & $11.73(4.8)$ & $6.11(4.2)$ & $9.98(4.5)$ & $63.84(7.5)$ & $1.62(1.6)$ & $0.06(0.3)$ & $3.58(2.1)$ & $3.08(2.4)$ \\
6 & $11.31(4.6)$ & $6.72(4.5)$ & $9.81(4.4)$ & $62.41(7.6)$ & $2.83(2.1)$ & $0.27(0.4)$ & $3.53(2.2)$ & $3.12(2.4)$ \\
12 & $11.25(4.6)$ & $6.81(4.7)$ & $9.80(4.4)$ & $62.28(7.6)$ & $2.85(2.1)$ & $0.34(0.4)$ & $3.54(2.2)$ & $3.13(2.4)$ \\
\hline
\end{tabular}

\begin{tabular}{lcccccccc}
\hline \multicolumn{7}{l}{ Forecast Error Variance of Outputgap as Explained by Shocks to } \\
\hline Horizon & oil & ffrate & outputgap & inf & neer & CMR & gm3 & $g b c$ \\
\hline 1 & $2.55(4.7)$ & $0.89(1.7)$ & $96.55(6.3)$ & $0.00(0.0)$ & $0.00(0.0)$ & $0.00(0.0)$ & $0.00(0.0)$ & $0.00(0.0)$ \\
3 & $3.58(5.2)$ & $1.06(1.2)$ & $79.81(7.2)$ & $0.19(0.7)$ & $7.81(4.0)$ & $2.98(1.9)$ & $0.11(0.4)$ & $4.47(2.6)$ \\
6 & $3.12(5.4)$ & $2.06(3.1)$ & $74.39(8.1)$ & $0.56(1.3)$ & $8.79(4.9)$ & $3.58(2.5)$ & $0.29(0.4)$ & $7.22(4.4)$ \\
12 & $3.09(5.4)$ & $2.14(3.4)$ & $74.19(8.2)$ & $0.60(1.3)$ & $8.81(4.9)$ & $3.61(2.5)$ & $0.32(0.4)$ & $7.25(4.4)$ \\
\hline
\end{tabular}

\begin{tabular}{lcccccccc}
\hline \multicolumn{2}{l}{ Forecast Error Variance of NEER as Explained by Shocks to } \\
\hline Horizon & oil & ffrate & outputgap & inf & neer & CMR & gm3 & $g b c$ \\
\hline 1 & $2.11(2.7)$ & $0.22(0.9)$ & $0.00(0.1)$ & $0.33(1.1)$ & $97.34(3.1)$ & $0.00(0.0)$ & $0.00(0.0)$ & $0.00(0.0)$ \\
3 & $6.91(5.7)$ & $0.24(0.8)$ & $11.55(5.1)$ & $0.92(1.3)$ & $76.76(8.2)$ & $0.79(1.2)$ & $1.03(1.5)$ & $1.03(1.50)$ \\
6 & $6.33(5.1)$ & $1.26(1.7)$ & $13.29(5.5)$ & $1.73(1.9)$ & $71.03(8.7)$ & $0.95(1.2)$ & $3.70(2.5)$ & $3.70(2.49)$ \\
12 & $6.31(5.1)$ & $1.42(1.9)$ & $13.30(5.5)$ & $1.77(2.0)$ & $70.72(8.8)$ & $0.99(1.2)$ & $3.77(2.5)$ & $3.77(2.51)$ \\
\hline
\end{tabular}

\begin{tabular}{lcccccccc}
\hline \multicolumn{2}{l}{ Forecast Error Variance of CMR as Explained by Shocks to } \\
\hline Horizon & oil & ffrate & outputgap & inf & neer & CMR & gm3 & $g b c$ \\
\hline 1 & $1.02(1.9)$ & $0.05(0.4)$ & $0.80(1.7)$ & $0.10(0.6)$ & $0.01(0.2)$ & $98.02(2.7)$ & $0.00(0.0)$ & $0.00(0.0)$ \\
3 & $0.83(1.6)$ & $0.18(0.7)$ & $0.76(1.6)$ & $2.49(3.2)$ & $4.69(3.9)$ & $86.90(6.0)$ & $1.41(1.7)$ & $2.75(2.8)$ \\
6 & $1.84(2.6)$ & $0.33(1.2)$ & $1.75(2.0)$ & $2.51(3.1)$ & $4.65(4.0)$ & $82.67(7.8)$ & $1.86(1.8)$ & $4.39(3.9)$ \\
12 & $1.98(2.8)$ & $0.68(2.1)$ & $1.86(2.2)$ & $2.48(3.1)$ & $4.60(3.9)$ & $81.48(8.8)$ & $1.83(1.8)$ & $5.09(4.4)$ \\
\hline
\end{tabular}

\begin{tabular}{lcccccccc}
\hline \multicolumn{1}{l}{ Forecast Error Variance of GM3 as Explained by Shocks to } \\
\hline Horizon & oil & ffrate & outputgap & inf & neer & CMR & gm3 & gbc \\
\hline 1 & $0.75(1.7)$ & $0.32(1.1)$ & $1.41(2.2)$ & $2.94(3.2)$ & $2.95(3.1)$ & $0.22(0.9)$ & $91.41(5.2)$ & $0.00(0.0)$ \\
3 & $1.33(2.5)$ & $0.52(1.2)$ & $6.39(3.7)$ & $4.13(3.5)$ & $5.79(3.6)$ & $0.29(0.9)$ & $76.31(6.7)$ & $5.25(3.8)$ \\
6 & $2.44(2.9)$ & $0.56(1.1)$ & $9.19(4.2)$ & $4.66(3.3)$ & $8.22(3.8)$ & $0.76(1.0)$ & $68.43(7.8)$ & $5.75(3.6)$ \\
12 & $2.44(2.9)$ & $0.63(1.1)$ & $9.25(4.2)$ & $4.69(3.2)$ & $8.29(3.8)$ & $0.82(1.0)$ & $68.02(8.0)$ & $5.86(3.6)$ \\
\hline
\end{tabular}

\begin{tabular}{lcccccccc}
\hline \multicolumn{2}{l}{ Forecast Error Variance of GBC as Explained by Shocks to } \\
\hline Horizon & oil & ffrate & outputgap & inf & neer & CMR & gm3 & gbc \\
\hline 1 & $0.00(0.1)$ & $0.36(1.2)$ & $14.97(6.3)$ & $0.04(0.4)$ & $0.22(0.8)$ & $9.98(5.0)$ & $25.64(6.4)$ & $53.77(7.2)$ \\
3 & $2.45(5.7)$ & $0.81(1.5)$ & $15.46(6.3)$ & $0.56(1.1)$ & $0.56(1.1)$ & $8.03(4.2)$ & $22.06(6.0)$ & $50.07(6.7)$ \\
6 & $4.33(6.7)$ & $1.31(2.1)$ & $16.46(6.6)$ & $0.60(1.0)$ & $0.77(1.0)$ & $7.79(4.0)$ & $20.72(6.0)$ & $48.02(8.1)$ \\
12 & $4.34(6.6)$ & $1.37(2.3)$ & $16.59(6.7)$ & $0.62(1.0)$ & $0.82(1.0)$ & $7.81(4.0)$ & $20.55(6.1)$ & $47.89(8.1)$ \\
\hline
\end{tabular}

Note: Figures in brackets are standard errors calculated via boot strapping method. 
Table 7: Estimated Structural Contemporaneous Coefficients

(Pure Inflation Targeting Case)

\begin{tabular}{|c|c|c|c|c|c|c|c|c|}
\hline & oil & ffrate & outputgap & inf & neer & $C M R$ & $g m 3$ & $g b c$ \\
\hline oil & $\begin{array}{l}7.941 * * * \\
(0.54)\end{array}$ & & & & & & & \\
\hline ffrate & $\begin{array}{l}-1.305^{*} \\
(0.77)\end{array}$ & $\begin{array}{l}7.652^{* * *} \\
(0.52)\end{array}$ & & & & & & \\
\hline outputgap & $\begin{array}{l}-2.463^{* * * *} \\
(0.79)\end{array}$ & $\begin{array}{l}-0.764 \\
(0.74)\end{array}$ & $\begin{array}{l}35.541 \text { *** } \\
(2.42)\end{array}$ & & & & & \\
\hline inf & $\begin{array}{l}5.107 * * * \\
(0.88)\end{array}$ & $\begin{array}{l}-1.729^{* *} \\
(0.75)\end{array}$ & $\begin{array}{l}9.742^{* * * *} \\
(3.48)\end{array}$ & $\begin{array}{l}253.068^{* * *} \\
(17.22)\end{array}$ & & & & \\
\hline neer & $\begin{array}{l}1.518 \\
(0.95)\end{array}$ & $\begin{array}{l}-0.466 \\
(0.76)\end{array}$ & $\begin{array}{l}0.741 \\
(3.55)\end{array}$ & $\begin{array}{l}14.837 \\
(24.37)\end{array}$ & $\begin{array}{l}59.916^{* * * *} \\
(4.08)\end{array}$ & & & \\
\hline$C M R$ & $\begin{array}{l}1.141 \\
(0.96)\end{array}$ & $\begin{array}{l}-0.253 \\
(0.76)\end{array}$ & $\begin{array}{l}0.000 \\
(0.0)\end{array}$ & $\begin{array}{l}13.303 \\
(23.50)\end{array}$ & $\begin{array}{l}0.000 \\
(0.00)\end{array}$ & $\begin{array}{l}0.415 * * * \\
(0.03)\end{array}$ & & \\
\hline gm3 & $\begin{array}{l}1.534 \\
(0.97)\end{array}$ & $\begin{array}{l}0.326 \\
(0.76)\end{array}$ & $\begin{array}{l}-2.656 \\
(3.56)\end{array}$ & $\begin{array}{l}42.356^{*} \\
(24.58)\end{array}$ & $\begin{array}{l}-10.785^{*} \\
(5.81)\end{array}$ & $\begin{array}{l}-0.020 \\
(0.04)\end{array}$ & $\begin{array}{l}149.198^{* * * *} \\
(10.15)\end{array}$ & \\
\hline$g b c$ & $\begin{array}{l}-0.222 \\
(0.98)\end{array}$ & $\begin{array}{l}0.840 \\
(0.76)\end{array}$ & $\begin{array}{l}16.114 * * * \\
(3.73)\end{array}$ & $\begin{array}{l}25.890 \\
(24.81)\end{array}$ & $\begin{array}{l}11.599 * * \\
(5.91)\end{array}$ & $\begin{array}{l}-0.173 * * * \\
(0.04)\end{array}$ & $\begin{array}{l}108.187^{\text {**** }} \\
(16.13)\end{array}$ & $\begin{array}{l}99.292 * * * \\
(6.76)\end{array}$ \\
\hline
\end{tabular}

